\title{
GROUND TEST STANDS FOR TESTING ROTORS IN INSULATED CONDITIONS
}

\author{
Małgorzata Wojtas (iD 0000-0003-3731-812X \\ Lukasz Czajkowski (iD 0000-0001-6090-0498 \\ Kazimierz Szumański (D) 0000-0003-2811-8505 \\ Łukasiewicz Research Network - Institute of Aviation, Al. Krakowska 110/114, Warsaw 02-256, Poland \\ Malgorzata.Wojtas@ilot.lukasiewicz.gov.pl \\ Lukasz.Czajkowski@ilot.lukasiewicz.gov.pl \\ Kazimierz.Szumanski@ilot.lukasiewicz.gov.pl
}

\begin{abstract}
The paper generally discusses Whirl Tower research stands. Whirl Tower stands are used to test, among others, rotorcrafts main rotors in hovering. The work presents an overview of similar solutions of test stand presented in the available literature and online data. Beyond these solutions the paper also contains test stands used so far at the Institute of Aviation, these solutions were prepared for testing one type of rotor (for example: only for gyroplane rotors).

The article provides information about new (Whirl Tower) test stand fully designed and manufactured in Łukasiewicz Research Network - Institute of Aviation ( that it will be a universal test stand, giving the possibility to test different types of rotors.

Moreover, the article discusses the types of tests and research that can be carried out on this type of test stand, tests that are performed to ensure the safety of the rotor design.
\end{abstract}

Keywords: main rotor, whirl tower, tests.

Type of the work: Research Paper

\section{INTRODUCTION}

In the last few years, the development of light and ultralight rotorcraft has been observed. This applies to both helicopters and gyroplanes. There are new solutions of ultra-light rotorcraft constructions that do not require certification tests. Modern flying devices available to the widest group of aviation enthusiasts (private customers and businessmen), which weight and performance are within the UL 115 subcategory. Recipients are oriented to new solutions, improvements that increase flight comfort, economy, distance and flight speed. In addition to the design of completely new rotorcraft solutions, great emphasis is placed on the development of new main rotors, with new airfoils and new technology of manufacturing using composite materials $[5,6,7]$.

New regulations exempting certain aircraft from certification do not exempt us from ensuring the safety of these designs. The primary structural elements in rotorcraft, which is undoubtedly the main rotor, are subjected to numerous tests before being permitted to fly on an aircraft. 
The paper presents a short review of test stands solutions for testing isolated rotors - so-called Whirl Tower tests stands. This type of test bench allows for testing the helicopter rotors in hover conditions without the need to test the whole helicopter.

Further the article discusses research possibilities of that kind test stands. Concurrently discussing the new Whirl Tower research stand designed and manufactured at the Łukasiewicz Research Network - Institute of Aviation.

\section{WHIRL TOWER TEST STAND OVERVIEW}

There are many test stand solutions around the world that enable the testing of load-bearing rotors and propellers. Examples of Whirl tower solutions are discussed below.

One of the solution - whirl tower test system, shown in figure 3, is discussed in the literature [2, 3]. This solution for rotorcrafts was designed and manufactured in Turkish Aerospace Industries. The main properties of this test stand are: rotor blades are mounted at $6 \mathrm{~m}$ high, the maximum motor power of the system is $560 \mathrm{~kW}$ with maximum torque $-7780 \mathrm{~N} / \mathrm{m}$, rotor revolution speed is $744 \mathrm{RPM}$ and maximum dimeter of tested rotor is $8 \mathrm{~m}$.
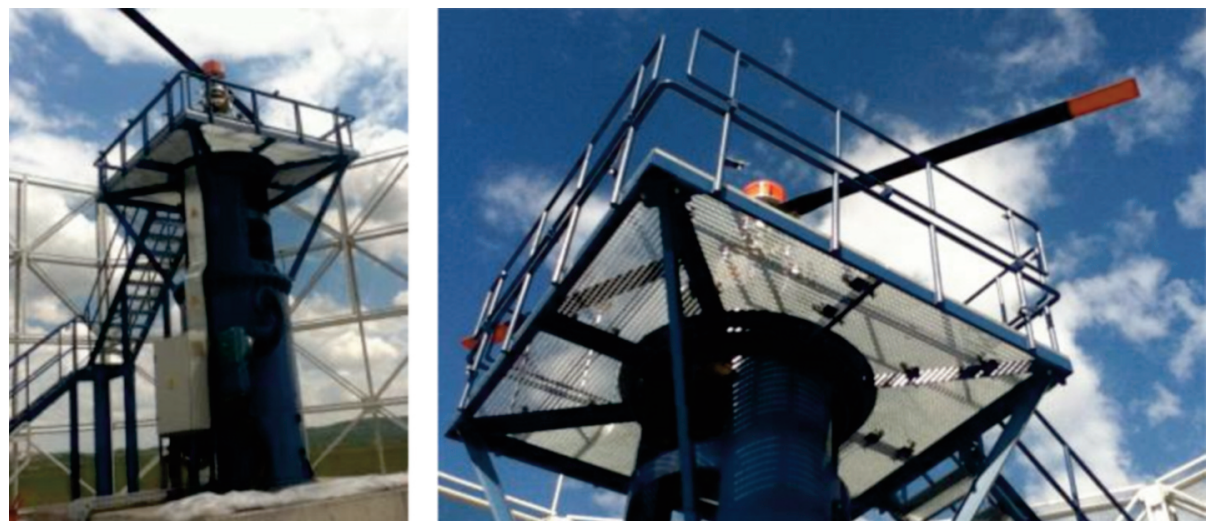

Fig. 1. The TAI whirl tower system [2].

Another solution is found in Korea Aerospace Research Institute [1]. KARI WTTF is a multipurpose whirl tower. It can be used for development test and production test (dynamic balancing test). The tower is equipped with universal hub systems, as shown on figure below. The stand has been prepared for the requirements for helicopters $8000 \mathrm{~kg}$ MTOW class.
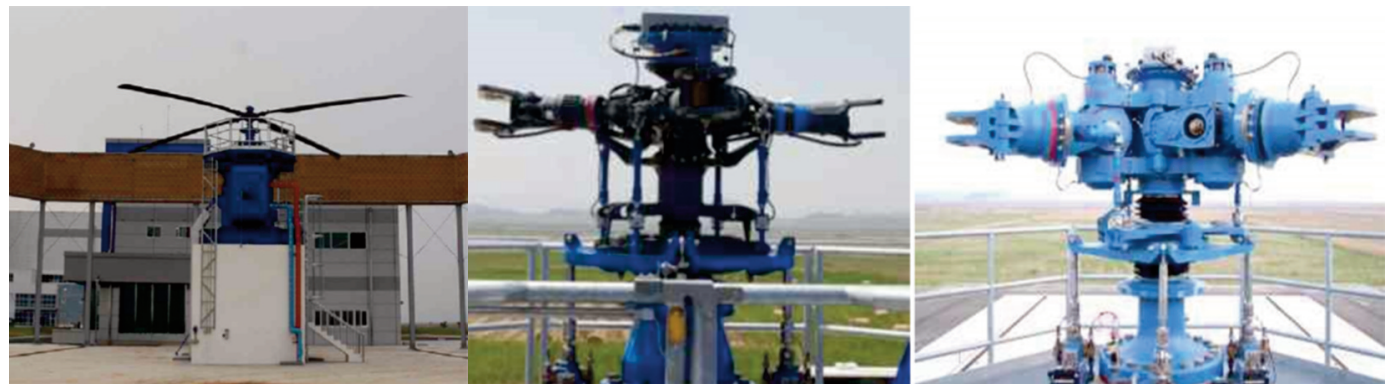

Fig. 2. KARI Whirl Tower Test Facility (WTTF). 
Similar solutions can be found, inter alia in Carleton University in Canada. A Whirl Tower enables the centrifugal testing of a rotary-wing apparatus, i.e. helicopter and wind turbine rotors or propellers, before entering a wind tunnel or flight test campaign [8].

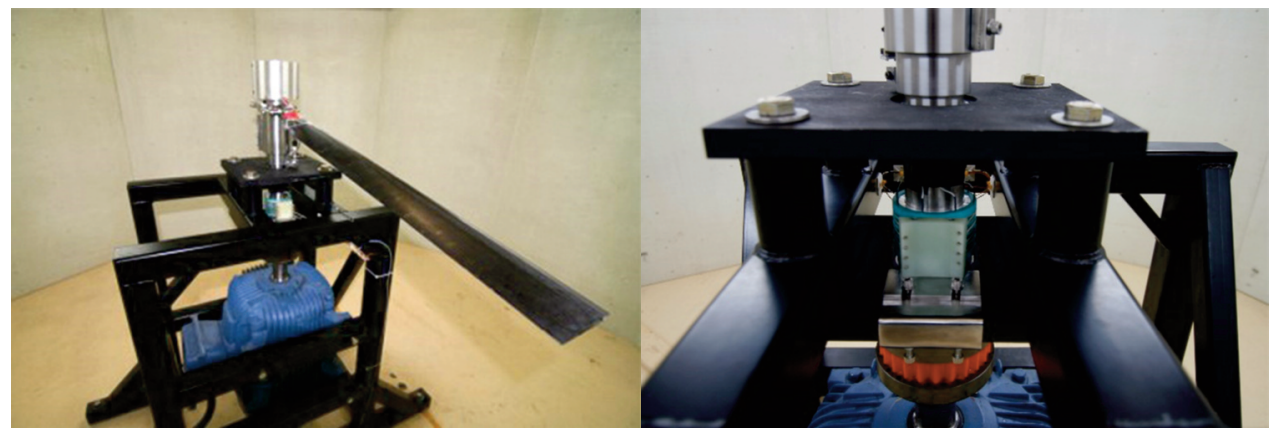

Fig. 3. The Whirl Tower Test Chamber and Test Stand [8].

It is driven by a $60 \mathrm{HP}, 575 \mathrm{~V} 3$-phase, $1.800 \mathrm{RPM}$ motor, which is controlled via a variable frequency drive/transformer. The whirl tower is located in a test chamber with a diameter of $15 \mathrm{ft}(4.57 \mathrm{~m})$ as show on figure above.

The Institute of Aviation several test stands of this type have been made. These positions were not as advanced as the above discussed constructions. The stands were designed and manufactured for testing specific construction solutions of main helicopter and gyroplane rotors performance as well as determination loads of rotor system (blade, hub) under normal operating conditions and under boundary conditions.

Below, there are three different designs of test stands for testing insulated rotors. Figure 4 shows the test stand dedicated to test IS -2 helicopter three blade main rotor. The stand consists of a symmetrical tower to which the gear and the original rotor hub of the helicopter were mounted. The drive was carried out by a combustion engine with a power about $200 \mathrm{HP}$.

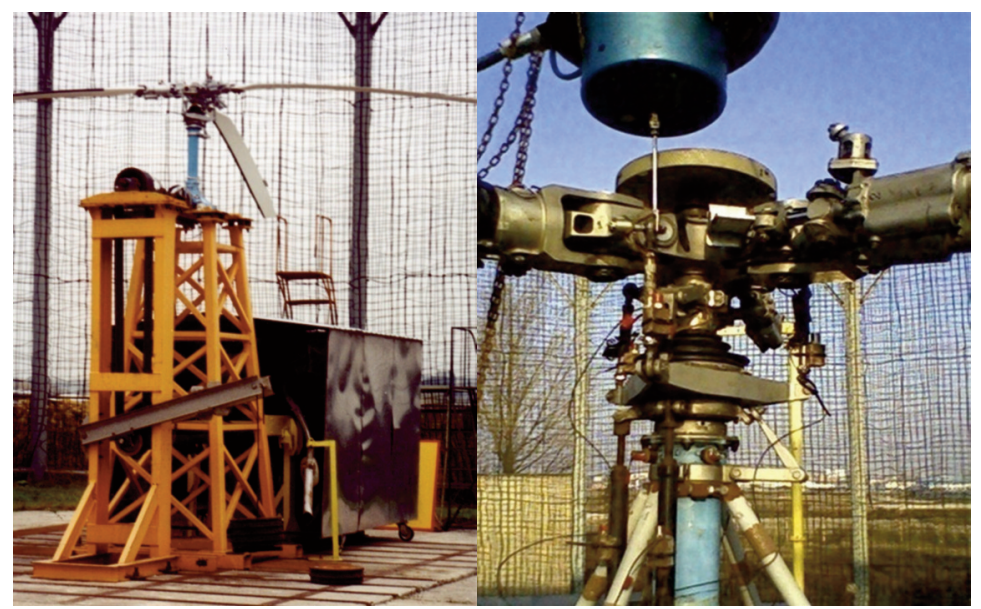

Fig. 4. The whirl tower system for helicopter three-blade main rotor [5]. 
Next test stand design was performed for the project titled 'New Autorotation Rotor', as a result of which new rotors, with new airfoil, dedicated to gyroplanes were designed and tested. Test position (shown in Fig. 5 left), was equipped with a rigid, two-bladed, universal teetering rotor, adequately oversized to ensure safety during tests. The maximum power of the stand was $180 \mathrm{HP}$. The distance between the blades and the ground was $3 \mathrm{~m}$.

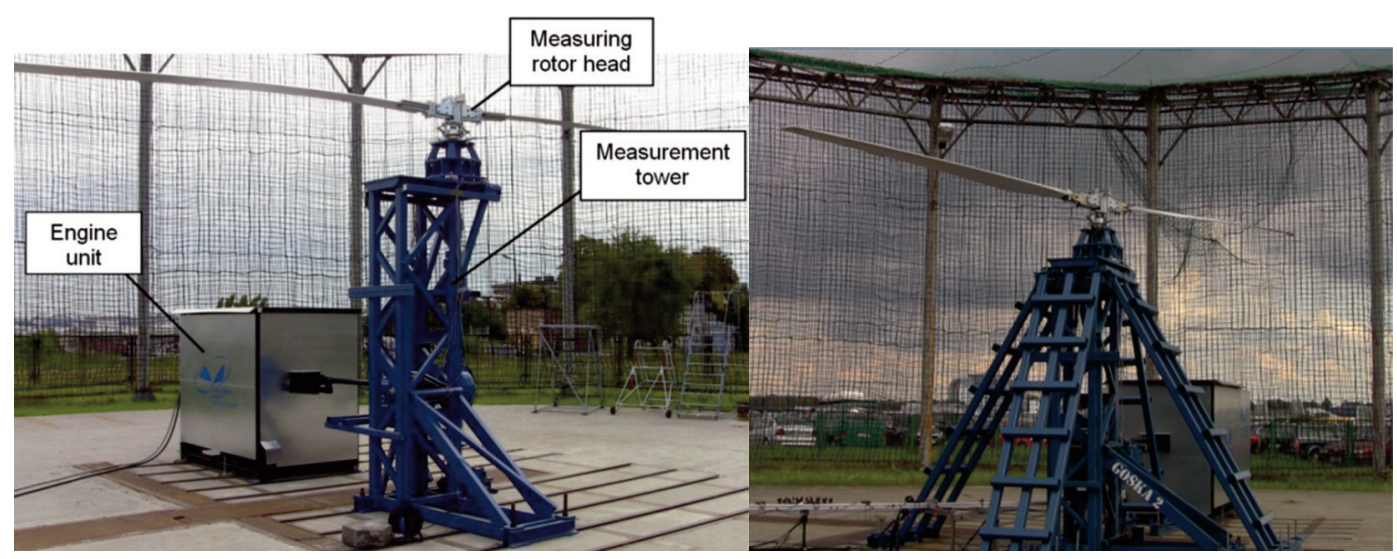

Fig. 5. The whirl tower system for gyroplane main rotor tests (left) and stiffened construction for testing helicopter rotors (right) $[4,5]$.

Whirl tower for the needs of another project, concerning the implementation of new composite (made in prepregs technologies) rotors for light and ultra light helicopters was modernized. During the preliminary tests it turned out that the resonance that occurs during the test achieves dangerously high level. After performing the resonance tests of the stand with additional loading mass and modal analysis, appropriate supports were designed, shown in Fig. 5 (right) [5].

Another position is presented below. It is a stand that allows conducted tests of the coaxial rotor head. The stand was powered by an $11 \mathrm{~kW}$ electric motor. The distance between the first rotor blades and the ground was $1 \mathrm{~m}$.

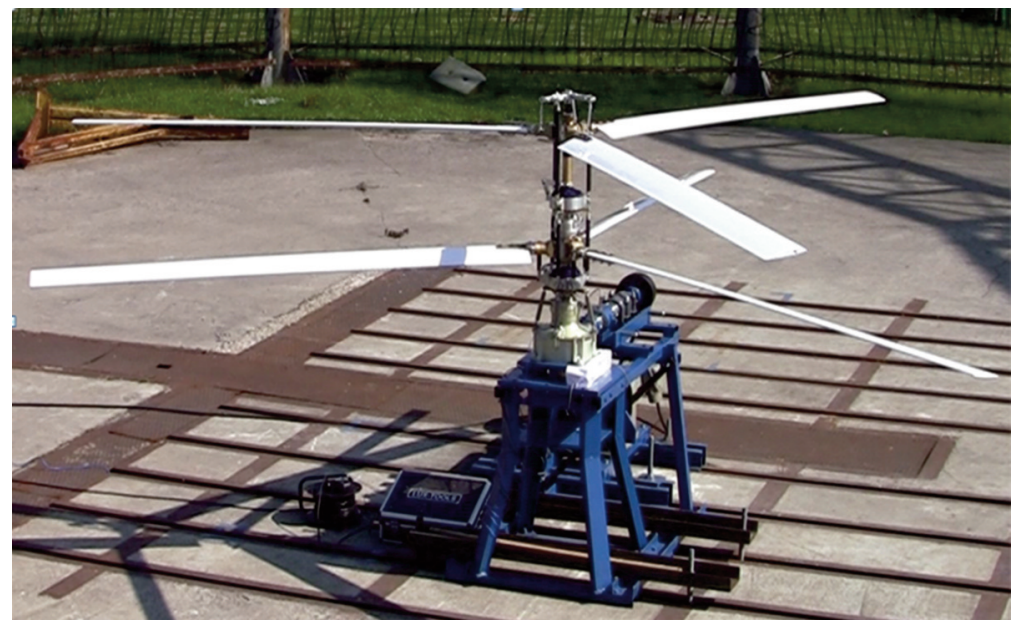

Fig. 6. Coaxial rotor whirl tower test stand. 


\section{3. Ł-ILOT WHIRL TOWER STAND}

Growing interest in research on new helicopter and gyrocopter rotors. Furthermore interest about the possibility, determining the various structures vibration which are within range of helicopter rotors. All this contributed to the development of a new whirl tower type test stand that will meet the requirements of the market [5].

As part of an internal project of the Aviation Institute, a unique research stand was design and manufactured. The test stand is equipped with a $410 \mathrm{HP}$ electric motor, the maximum torque is approximately $5000 \mathrm{Nm}$, maximum rotor speed is approximately $1000 \mathrm{RPM}$. The tower is $4.5 \mathrm{~m}$ high - by $4 \mathrm{~m}$ diameter of main rotor the ground effect is low, for bigger rotor is posible to change the direction of the thrust vector.

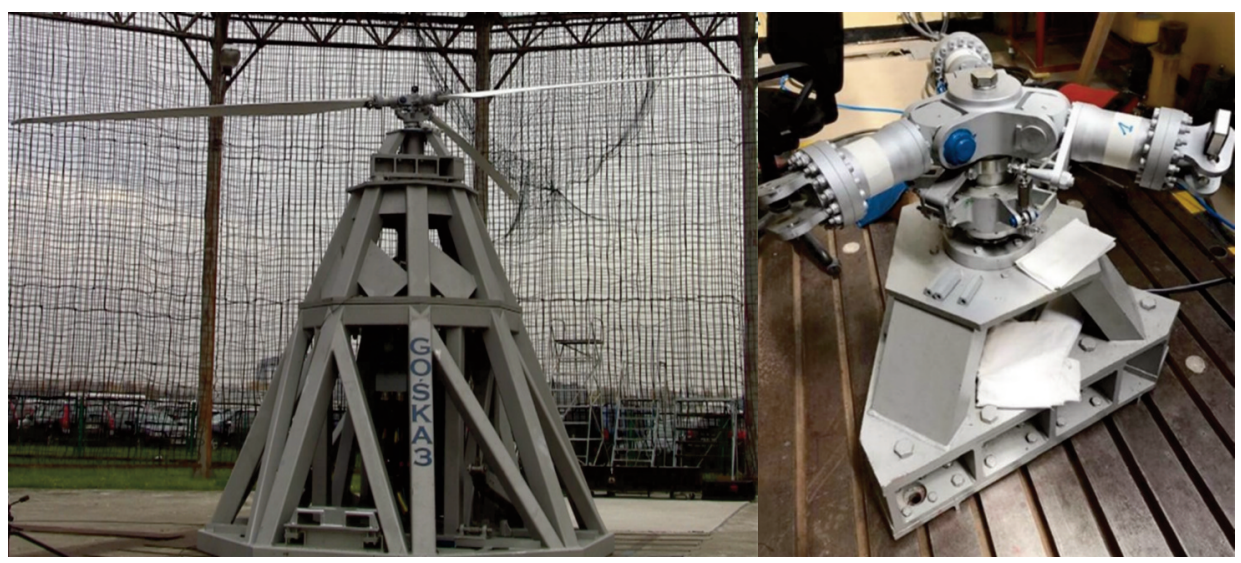

Fig. 7. The rotor test stand (left), three blade semi-grid rotor head (right) [5].

The stand is equipped with real time aqusition system - basic measured values - torque, power consumed, rotational speed, thrust and vibrations. Fast cameras sytem for blade tracking and balancing. The stand system has the ability to control and change the collective pitch. Universal test heads are the advantage of the stand. Three different heads are available such as semi-rigid 3 or 2-blade heads and teetering rotor. There is also ability to adapt original rotor head to the test stand. Addicionaly The electric power of this tower enabled the noise measurements at this stand.

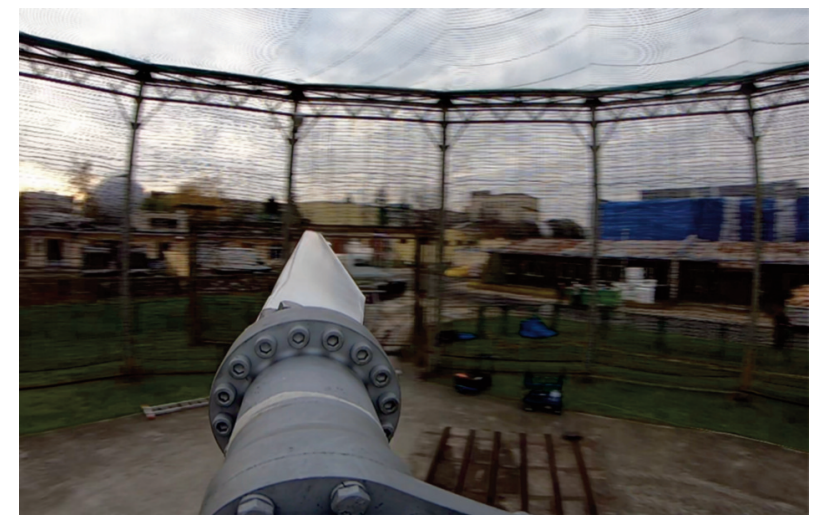

Fig. 8. Blade view during testing (from go-pro camera). 


\section{MEASUREMENT AND TESTS POSSIBILITIES}

To evaluate structural and aeromechanical performance of the main rotor, tests simulating hover conditions are carried out. Since precious information regarding dynamic balance, noise, aeroelastic stability, vibration and performance as well as structural integrity of rotors at hover condition can be assessed in Whirl Tower tests, these test systems are considered vital in rotor design. [5]. Several research/tests options, of the discussed test stand in chapter 3, are listed and described below.

The data acquisition system allows for the measurement of basic parameters such as rotor torque, rotor rotational speed, thrust and real-time measurement and observation of vibrations occurring on the stand during the test in three axes. Additionally, it is possible to measure the forces on the pusher in a non-rotating configuration. The independent high-speed View Works cameras system with a dedicated measurement application enables dynamic tracking and balancing of the rotor.

The test stand and system have been designed it that way so it can be modified and adapted to more sophisticated tests without a lot of work and costs. For example it possible to add additional sensors, such as: acceleration sensors, distance or force sensors, whether to adjust or change test heads or use additional masses detuning the rotor system, etc. Thanks to a change in the stand and measurement system, it is possible to carry out tests, among others:

- determination of rotor (blades and heads) loads showing under normal and boundary conditions;

- aeroelastic phenomena such as: blade flutter or phenomenon of "weaving", "interlacing" characteristic of teetering rotors,

- propagation of damage after damage caused during rotating the rotor;

- tests simulating the "jumping start" of gyroplanes - using a modified head with a system for "jump start".

Using additional equipment, it is possible to perform aerodynamic a measurements such as:

- pulsation of the pressure of the rotor stream on the ground;

- trace of the rotor stream;

- aerodynamic optimization (blade geometry, profile distribution), and also

- rotor noise tests (as shown in figure 9).
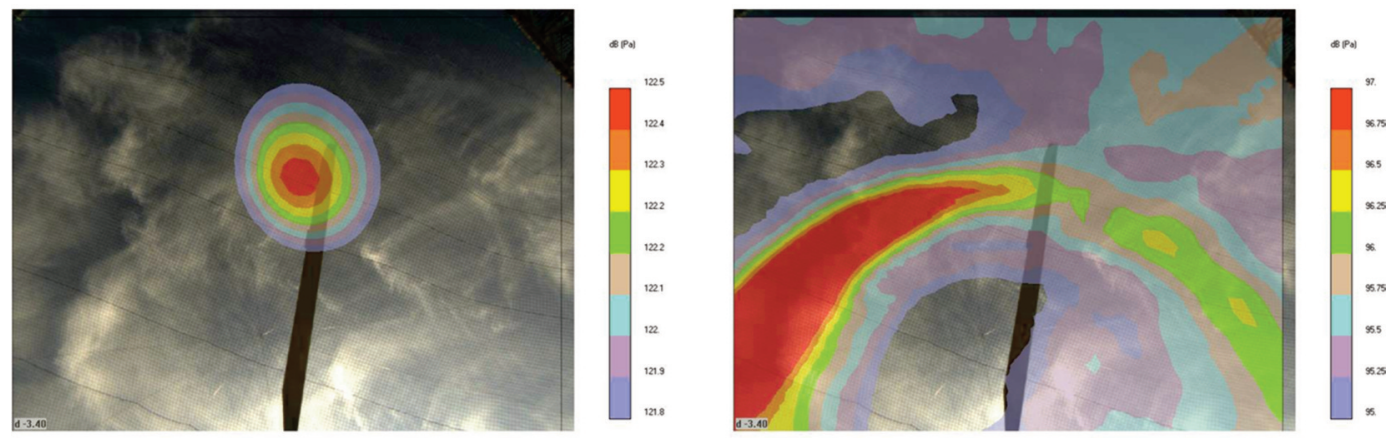

Fig. 9. Noise of rotor blade tip: image with synchronized rotation of the rotor (left); image with nonsynchronized rotation of the rotor (right). 


\section{TEST AND RESULTS EXAMPLES}

In $€$-ILOT tests of different helicopter and gyroplane rotors have been conducted so far. All rotors tested on the test stand were an innovative solutions in terms of design, aerodynamics or both. Some examples of the use of research are presented below.

\section{a. Gyrocopter rotor performance tests}

In the project "Modern autorotation rotor", three different rotors were tested. Two aluminum rotors, with different aerodynamic profiles, for ultra-light and light ( $\mathrm{B}$ and $\mathrm{C}$ class) gyroplanes, and a composite rotor dedicated to four or six-seat gyroplanes (A class). The tests were carried out to validate the aerodynamic calculations and to check the new airfoils developed at the Łukasiewicz Research Network - Institute of Aviation.

The characteristics of the rotor obtained from the experiment at the positions are presented below. The characteristics shows the performance of the gyroplane rotor with a new airfoil ILW-LT-11.0 (designed in $\mathrm{E}$-ILOT).

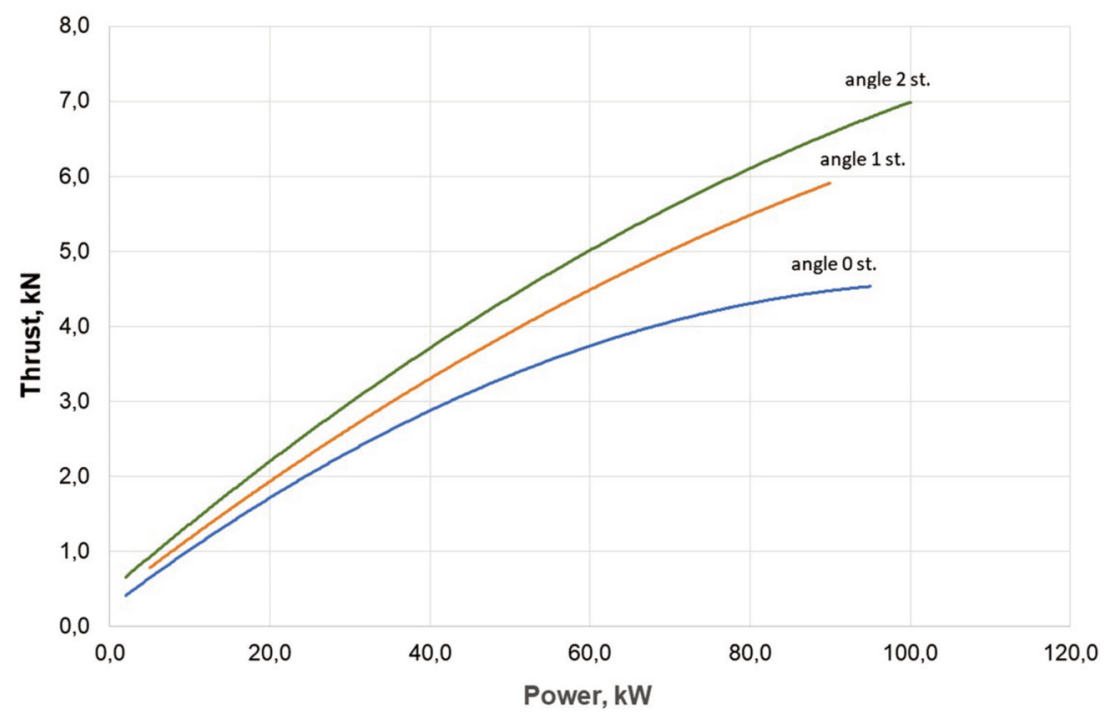

Fig. 10. Gyroplane main rotor characteristic for various angles of blade root.

The characteristics show the rotor performances at different angles of the blade root. The analyzes allowed for the selection of the optimal blade root angle, allowing to obtain the best performance of the gyroplane during the flight.

\section{b. Dynamic balancing and tracking}

An important aspect in the research of rotors is their good balance. Blade tracking is performed for two reasons: to check their balance before further bench tests, and to prepare the blades for flight tests. It is important that the blade tips follow the track. The difference that is allowed is the thickness of the blade tip. 


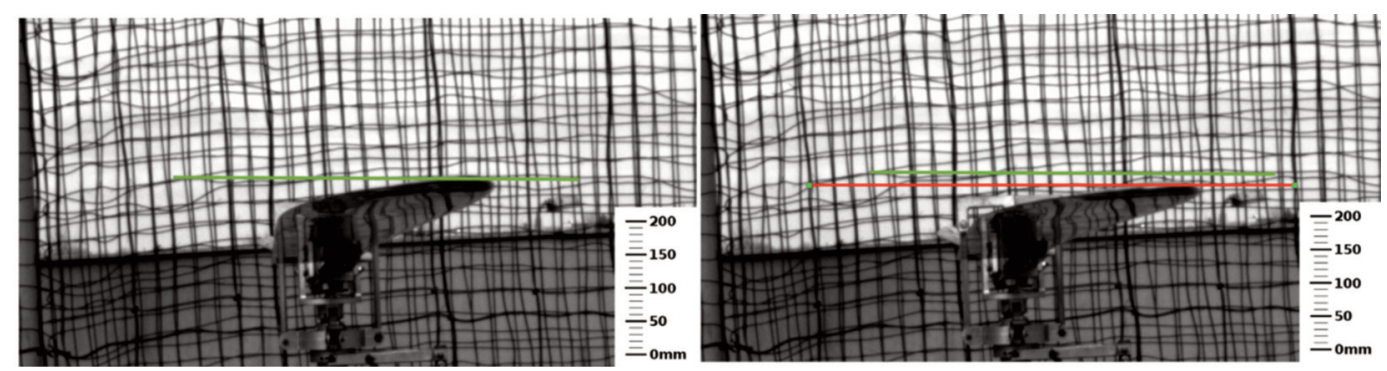

Fig. 11. Blades tracking with high-speed cameras.

The figure above shows the tracking of the newly developed blades dedicated to the A-class gyroplanes. The tests were carried out prior to flight tests.

\section{c. Aerodynamics calculation validation}

One of the projects carried out at the Łukasiewicz Research Network - Institute of Aviation concerned the development and manufactured new blades for an unmanned helicopter ILX-27. To validate assumptions and aerodynamic calculations comparative tests were performed. Tests were carried out to previous rotor and new (current) rotor. The graph below shows the comparison of the two rotor characteristic for constant rotational speed of 430 RPM, at different angles of the collective pitch.

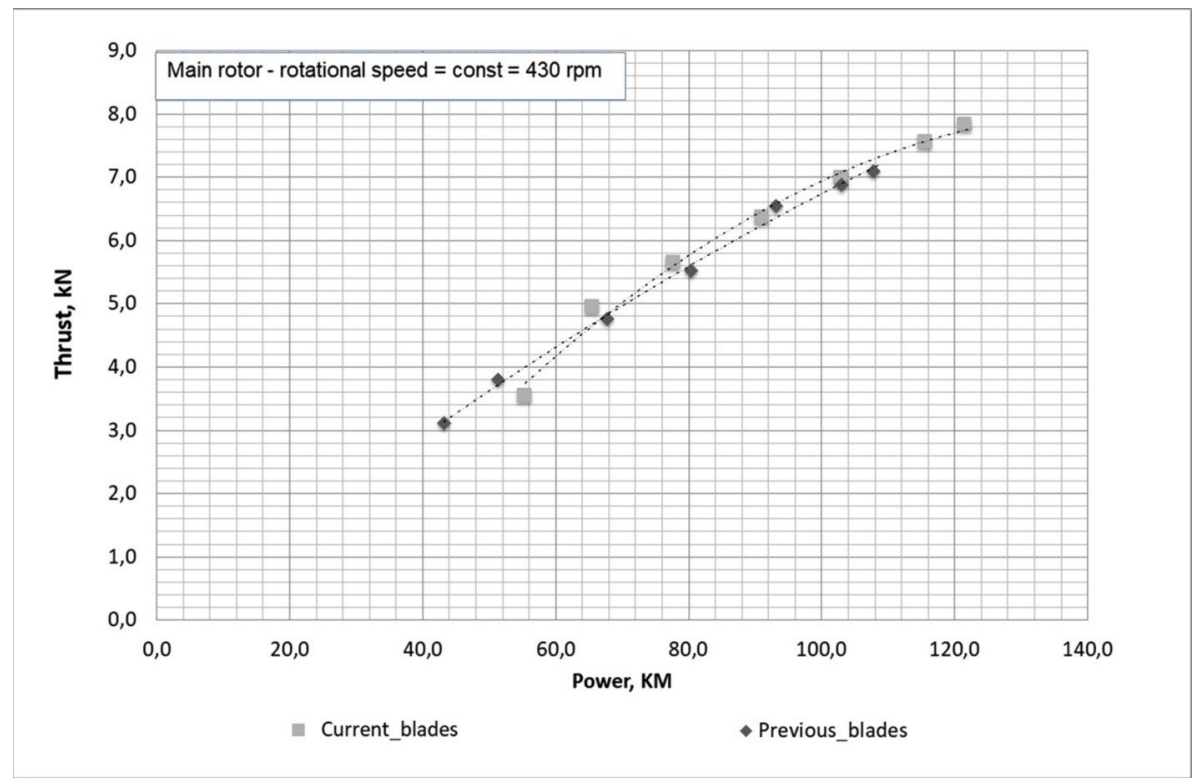

Fig. 12. The pole characteristic of the rotors.

The experiment shows that the new rotor, performance has improved by about 3-5\%, which coincides with the aerodynamic analyzes. 


\section{CONCLUSION}

Whirl towers type research stands are used by many companies dealing in the design, manufacturing and testing of rotorcrafts. Such test stands have in their possession companies from 'General Aviation' sector as well as small private companies and R\&D Institutes. The development of small rotorcraft in the new UL-115 category, the development of new rotors equipped with new aerodynamic profiles, produced with the use of the latest technologies, requires dissemination of research techniques that ensure the safe use of these design. It provides both safety during tests and safety in their use. Additionally, thanks to the new, more accurate data, it allows for the development of better structures with more advanced design.

\section{REFERENCES}

[1] Deog-Kwan, K., et al., 2012, "An operational test and dynamic balancing sensitive study of the rotor blade on the whirl tower", 38th European Rotorcraft Forum, Amsterdam, 1, pp. 412-421.

[2] Ergul, B.P., Yasa, O.A. and Tursun, G., 2013, "Determination of structural integrity of teetering rotor system by whirl tower tests”, 39th European Rotorcraft Forum, Moscow.

[3] Ezertas, A., Yucekayali, A. and Ortakaya, Y., 2013, "Hover performance assessment of 3 meter radius rotor on whirl tower", 39th European Rotorcraft Forum, Moscow.

[4] Sobieszek, A. and Wojtas, M., 2016, "Composite rotor blades tests essential before mounting on gyroplane”, Journal of KONES Powertrain and Transport, 23(4), pp. 487-494.

[5] Szczepanik, T., 2016, "Analysis of the state of the gyroplane world market", Transactions of the Institute of Aviation, 3(244), pp. 227-238.

[6] Wojtas, M. and Czajkowski, Ł., 2019, "A prototype test stand for testing insolated rotor systems", Journal of KONES Powertrain and Transport, 26(3), pp. 257- 264.

[7] Żurawski, R., 2014, Safe testing of rotating object prototypes, in: Safety on land, sea and in the air in the 21st century (in Polish), ISBN 978-83-61520-02-3, CNBOP-PIB, Józefów.

https://www.cnbop.pl/wydawnictwa/ksiazki/978-83-61520-02-3/bezpieczenstwo_na_ladzie_ morzu_i_w_powietrzu.pdf

[8] www.smartrotorsystems.ca

\section{NAZIEMNE STANOWISKA BADAWCZE DO BADANIA WIRNIKÓW W WARUNKACH IZOLOWANYCH}

\section{Abstrakt}

W artykule omówiono ogólnie stanowiska badawcze typu Whirl Tower. Stanowiska Whirl Tower służą do badania m.in. wirników głównych wiropłatów w zawisie. W pracy przedstawiono przegląd podobnych rozwiązań stanowisk badawczych prezentowanych w dostępnej literaturze i danych internetowych. Poza tymi rozwiązaniami w pracy przedstawiono również stanowiska dotychczas stosowane w Instytucie Lotnictwa, które były przygotowane do badania jednego typu wirnika (np. tylko dla wirników żyrokopterów).

W artykule podano informacje o nowym stanowisku (Whirl Tower) w całości zaprojektowanym i wykonanym w Sieci Badawczej Łukasiewicz - Instytucie Lotnictwa. Jednym z podstawowych założeń jest to, że będzie to stanowisko uniwersalne, dające możliwość badania różnych typów wirników.

Ponadto w artykule omówiono rodzaje testów i badań, które mogą być prowadzone na tego typu stanowisku, testów, które wykonuje się w celu zapewnienia bezpieczeństwa konstrukcji wirnika.

Słowa kluczowe: wirnik główny, wieża wirowa, badania. 